\title{
To the prevention of infectious diseases in chickens
}

\author{
Nadezhda Momot $^{1}$, Yulia Kolina ${ }^{1, *}$, Alexey Trebukhov ${ }^{2}$, Svetlana Terebova, and Yulia \\ Chekunkova ${ }^{3}$ \\ ${ }^{1}$ Primorye State Agricultural Academy, 692510, Ussuriysk, Russian Federation \\ ${ }^{2}$ Altai State Agricultural University, 656049, Barnaul, Russian Federation \\ ${ }^{3}$ Federal Altai Scientific Centre of Agro-BioTechnologies, 656910, Barnaul, Russian Federation
}

\begin{abstract}
Newcastle disease affects birds of different breeds and ages (turkeys, quails, guinea fowls, chickens). Given the possibility of spreading the disease by birds of other species, including migratory birds, it makes more sense to immunize chickens during their long-distance migration. The main measure of disease prevention remains its competent specific prevention with the use of live and inactivated vaccines, as the specialists of the Khankai branch of the Khorol Veterinary Station for animal diseases control told the public. The only way to protect against the disease is to vaccinate all types of poultry.
\end{abstract}

\section{Introduction}

The development of the agro-industrial complex in the country involves obtaining highquality agricultural products [1-6]. At the same time, timely diagnostics and prevention of diseases makes it possible to identify various pathologies in time and take the necessary measures to eliminate them [7-10]. Infectious diseases of animals that cause great harm to animal husbandry and poultry farming are widespread [11-13]. The Newcastle disease is the most dangerous viral disease of birds, capable of destroying up to $70 \%$ of all livestock. Its outbreaks are regularly recorded all over the world, and its detection on the farm involves serious anti-epizootic measures that cause huge financial damage. The causative agent of the disease belongs to the family Paramixoviridae, the genus Avulavirus. The source of infection is sick and ill birds. Recently, various properties of the Newcastle disease virus, including oncolytic ones, have been carefully studied [14, 15]. The Newcastle disease has not been reported in Primorye since 2009. Nevertheless, after one decade, individual epizootics of the disease reappeared on the territory of the region. In May 2019, quarantine for Newcastle disease was introduced in the village of Komarovka, located on the territory of the Kirovsky district of the Primorsky Krai, where three epizootic foci were recorded, confirmed by laboratory diagnostic methods. Restrictive measures were introduced on the territory of the rural settlement on the basis of the approved comprehensive plan of preventive measures. The disease was eliminated by the measures taken to combat it. Nevertheless, at the end of 2019, two new outbreaks of the disease were detected in chickens in the rural settlement of Novoselishche in the Khankai district of the

* Corresponding author: momot18@mail.ru 
Primorsky Krai. The first threatened zone included the following villages: Udobnoe and Alekseyevka. During the period of the imposed quarantine, outsiders are not allowed in these villages. It is prohibited to move inside the farm, export poultry, eggs and other poultry products, as well as export forage, inventory, equipment and droppings. All the chickens available in the farms of the villagers were examined, vaccinated and constantly monitoring for their condition was carried out. In epizootic foci, disinfection of household premises and places where poultry was kept was carried out. Regular monitoring of her condition is conducted. Like most other viruses, the causative agent of this disease is prone to mutations and changes in its antigenic properties. Currently, more than a dozen strains of the virus are known, so vaccine manufacturers indicate on the packaging which strain the drug is made from. Since the La-Sota and Bor-74 strains are widely distributed in the CIS countries, young chickens are vaccinated with drugs that form immunity to these strains. The purpose of the work: implementation of preventive measures against the Newcastle disease in young chickens of different ages in a private farmstead.

\section{Materials and methods of research}

In a private subsidiary farm owned by a private individual M. and located within the Ussuriysk district of the Primorsky Krai, preventive measures were carried out aimed at preserving the bird population. The main proactive measure to prevent the disease was the vaccination of young animals with the use of a vaccine against the Newcastle disease from the "La Sota" strain, which was used taking into account all the necessary measures set out in the instructions for combating this disease. The dry live vaccine with an immunostimulator, used by us for preventive purposes, had a dry, uniform mass of light yellow or light brown color, which easily dissolves in water without the formation of sediment or flakes. All young chickens kept on the territory of a personal subsidiary farm were subjected to a veterinary inspection. Clinically healthy poultry were divided into three groups, taking into account age: - the first group consisted of chickens aged from one to twenty-five days; - the second group was formed by chickens aged from 30 to 60 days; - the third group consisted of chickens older than 60 days. Prior to vaccination, no chemotherapeutic agents were prescribed to the bird for 3-5 days, which can be used only after vaccination in 5-7 days.

Among the two main forms of vaccines against the Newcastle disease, we used a dry live-viral vaccine used for young chickens of different breeds aged 10-14 days, and for emergency immunization of all livestock in cases where the disease is detected at the poultry farm itself or within a radius of $10 \mathrm{~km}$ around it. Another form of the vaccine (inactivated) has a scope of application mainly for adult poultry-broiler breeding stock and egg breeds at the age of 3-4 months.

Vaccination was carried out by bottle-feeding.

\section{Results and discussions}

During the use of medicinal products that have a direct medicinal purpose, we observed not only the rules of personal hygiene, but also the safety measures provided for by the rules for the use of biological products for veterinary purposes. During the vaccination, all persons admitted to this event had not only rubber boots, a robe, trousers, a headdress, rubber gloves, but also respirators as personal protective equipment. For vaccination by bottle-feeding, the contents of the bottle were diluted with chilled boiled water.

The vaccine solutions for different age groups of chickens had different concentrations. Immunization of chickens of the first age group (1-25 days) was carried out with more 
enriched solution of dry live vaccine, but bottle-feeding doses were minimal and amounted to $5 \mathrm{ml}$ (Table 1).

Table 1. Vaccination of chickens from birth to 25-day-old age

\begin{tabular}{|c|c|c|}
\hline $\begin{array}{c}\text { Bottle with quantitative } \\
\text { indicators of intranasal } \\
\text { doses }\end{array}$ & $\begin{array}{c}\text { Chilled boiled } \\
\text { water, ml }\end{array}$ & $\begin{array}{c}\text { Quantitative } \\
\text { indicators of bottle- } \\
\text { feeding, } \mathrm{ml}\end{array}$ \\
\hline 1000 & 500 & 5 \\
\hline
\end{tabular}

The vaccine prepared for use in the morning was placed in clean drinking bowls for bottlefeeding for two days in a row. In the evening, the drinkers were thoroughly washed with water, while no disinfectants were used. Vaccination should be carried out after the bird has been previously kept for 2-4 hours without water and feed. Only after vaccine bottlefeeding after 1.5 hours, the feed and water were given.

In the second age group, less concentrated solution of the vaccine was used in comparison with the first group, but a higher dose $-10 \mathrm{ml}$ per chicken (Table 2) - was used for the vaccination by bottle-feeding method per 100 immunized chickens (Table 2).

Table 2. Vaccination of chickens of 30-60 days of age

\begin{tabular}{|c|c|c|}
\hline $\begin{array}{c}\text { Bottle with quantitative } \\
\text { indicators of intranasal } \\
\text { doses }\end{array}$ & $\begin{array}{c}\text { Chilled boiled } \\
\text { water, } \mathrm{ml}\end{array}$ & $\begin{array}{c}\text { Quantitative } \\
\text { indicators of bottle- } \\
\text { feeding, ml }\end{array}$ \\
\hline 1000 & 1000 & 10 \\
\hline
\end{tabular}

The young birds actually consume the biological product by themselves and receive protection from the Newcastle virus. The live vaccine forms a stable and intense immunity to this disease.

During vaccination by bottle-feeding in the third age group, the least concentrated vaccine was used at a feeding dose of $15 \mathrm{ml}$ per chicken (Table 3 ).

Table 3. Vaccination of chickens older than 60 days of age

\begin{tabular}{|c|c|c|}
\hline $\begin{array}{c}\text { Bottle with quantitative } \\
\text { indicators of intranasal } \\
\text { doses }\end{array}$ & $\begin{array}{c}\text { Chilled boiled } \\
\text { water, } \mathrm{ml}\end{array}$ & $\begin{array}{c}\text { Quantitative indicators } \\
\text { of bottle-feeding, } \mathrm{ml}\end{array}$ \\
\hline 1000 & 1500 & 15 \\
\hline
\end{tabular}

The unused vaccine was decontaminated for $0.5 \mathrm{~h}$ by treatment with a solution consisting of an equal volume of $5 \% \mathrm{NH}_{2} \mathrm{Cl}$ (chloramine) solution and $2 \%$ alkali solution. Special precautions are not required for the vaccine disposal.

There are no restrictions on the sale of products obtained from bird vaccinated with a live vaccine for this disease.

\section{Conclusions}

In this way, when studying the epizootic situation in the Primorsky Krai and the measures taken to combat the infectious disease (Newcastle disease), which causes great damage to poultry farming due to high mortality, it is necessary to note the following:

- despite the fact that the territory of the Primorye has been safe for many infectious diseases for many years, nevertheless, individual epizootic foci of the Newcastle disease were detected in 2019 in the Kirovsky and Khankai districts in personal subsidiary farms;

- not only domestic but also wild birds of different breeds and ages are exposed to infection, which pose the main threat to birds, both of industrial poultry farming and personal farmsteads; 
- $\quad$ given the possibility of spreading the disease by birds of other species, including migratory birds, it makes more sense to immunize chickens during their long-distance migration;

- the main measure of the Newcastle disease prevention remains its competent specific prevention with the use of live and inactivated vaccines, as the specialists of the Khankai branch of the Khorol Veterinary Station for animal diseases control told the public;

- the only way to protect against a particularly dangerous disease is to vaccinate all types of poultry, including young one;

- veterinary specialists of the region in 2019 took effective measures to combat the infection that is dangerous for poultry, which led to the improvement of the designated territories;

- $\quad$ proactive measures taken to prevent infection in the Primorye regional territories have led to positive results: throughout 2020 and the first months of this year, the Primorye is free from dangerous viral disease.

\section{References}

1. N.V. Momot, Yu.A. Kolina, Veterinary and sanitary assessment of the quality of poultry meat products, Actual issues of food production development: technologies, quality, ecology, equipment, management, and marketing. Proceedings of the IV National (All-Russian) Scientific and Practical Conference. Editor-in-chief S.V. Inshakov, Ussuriysk, 45-48 (2020)

2. A.V. Trebukhov A.A. Elenshleger, S.P. Kovalev [et al.], Ketosis of cows and calves: textbook, 132 (St. Petersburg: Lan, 2019)

3. N.V. Momot, Yu.A. Kolina, I.L. Kamliya, S.V. Terebova, Hippology and veterinary medicine. 1 (39), 142-146 (2021)

4. Kh.A. Safarov, Z.B. Mamatova, Internauka 21-3 (150), 67-69 (2020)

5. R.T. Abdyldaeva, Bulletin of the Kyrgyz National Agrarian University named after K.I. Scryabin 1 (37), 168-171 (2016)

6. N.V. Momot, Yu.A. Kolina, I.L. Kamliya, S.V. Terebova, Hippology and veterinary medicine 1 (39), 142-146 (2021)

7. A.Trebukhov, A. Elenshleger, IOP Conference Series: Earth and Environmental Science 341, 012152 (2019) Doi: 10.1088/1755-1315/341/1/012152

8. A.V. Trebukhov, Agrarian Russia 11, 5-7 (2016)

9. A.V. Trebukhov, Bulletin of the Altai State Agrarian University 1 (171), 50-55 (2019)

10. E.S. Stepanenko, Yu.S. Lushchay, Bulletin of the Altai State Agrarian University 4 (174), 78-82 (2019)

11. N.V. Momot, Yu.A. Kolina, I.L. Kamliya, S.V. Terebova, Pig breeding 7, 58-59 (2020)

12. N.V. Momot, Yu.A. Kolina, I.L. Kamliya, Bulletin of the Altai State Agrarian University 11 (193), 99-102 (2020)

13. A.V. Prudnikov, B.Ya. Burman, V.S. Prudnikov, Immunogenesis and immunity intensity in early-age broiler chickens vaccinated against infectious bronchitis and the Newcastle disease, Actual problems of veterinary medicine. Materials of the International Scientific and Practical Conference dedicated to the 125th anniversary of Veterinary Medicine of the Kursk region, 317-320 (2008) 
14. M.V. Podolskaya, S.M. Milyukov, The first domestic experience of the use of the oncolytic virus of the Newcastle disease in the complex treatment of malignant neoplasms, Actual issues of experimental and clinical oncology. Collection of materials of the All-Russian Conference of Young Oncologists dedicated to the memory of RAMS Academician N.V. Vasilyev, 139-142 (2016)

15. K.S. Yurchenko, N.V. Gubanova, L.V. Shestopalova, M.Yu. Shchelkanov, A.M. Shestopalov, Pacific Medical Journal 3 (61), 14-18 (2015) 